Hlibov. "Tsyatskovanuy osel"]. Selected works. Publishing house of children's literature "Rainbow", Kyiv. p. 31. [in Ukrainian].

3. Kiberbulinh, abo virtualna ahresiia: sposoby rozpiznannia i zakhyst dytyny [Cyberbullying, or virtual aggression: the ways of recognition and protection of child]. L.A.Naidonova; (Ed). V.O.Snihulska. Kyiv, 2014.96 p. [in Ukrainian].

4. Naumets Iryna (2020). Bulinh naiposhyrenishyi proiav dyskryminatsii dytyny [Bullying is the most common form of child discrimination]. Available at: https:/ /ipress.ua/articles/buling nayposhyrenishyy proyav dyskryminatsii_dytyny 159986.html [in Ukrainian].

5. OON opublikuvav nevtishnu statystyku bulinhu $\mathrm{v}$ ukrainskykh shkolakh (2020). [The UN has published disappointing statistics of bullying in Ukrainian schools]. Available at: https://ua.news/ua/oon-opublikuvav- nevtishnu-statistiku-bulingu-v-ukrayinskih-shkolah/ [in Ukrainian].

6. Ukraina - v liderakh sered krain Yevropy, de poshyrenyi shkilnyi bulinh (2018). [Ukraine is among the leaders among European countries where school bullying is widespread]. Available at: https://24tv.ua/health/ ukrayina__v_liderah_sered_krayin_ yevropi de poshireniy shkilniy buling n1054828[in Ukrainian].

7. Bullying in schools: self reported anxiety, depression, and self esteem in secondary school children. 2020. Available at: https://www.researchgate.net/publication/ 13528815_Bullying_in_schools_Self_reported_anxiety depression_and_self_esteem_in_secondary_school_children [in English].

8. Wang J., Nansel R. Tonja, Iannotti J. Ronald (2011). Cyber and traditional bullying: differential Assosiation with depression. Journal of Adolescent Health. V. 48. (№4). pp. 217-415. [in English].

Стаття надійшла до редакції 28.04.2020

УДК 377.36:745.05:332.1

DOI:

Лідія Сліпчишин, доктор педагогічних наук, стариий дослідник, доиент кафедри теорії і методики технологічної освіти, креслення та комп ютерної графіки Національного педагогічного університету імені М.П. Драгоманова, м. Київ

\title{
ВНЕСОК ПРОФЕСІЙНОЇ (ПРОФЕСІЙНО-ТЕХНІЧНОӦ) ОСВІТИ У ВІДРОДЖЕННЯ ВІТРАЖНОГО МИСТЕЦТВА НА ЛЬВІВЩИНІ
}

Розглянуто внесок професійної (професійно-технічної) освіти у відродження вітражного мистецтва на Західній Україні та зокрема на Львівщиині. Обгрунтовано взаємозв'язокрозвитку вітражсного мистецтва з соціально-економічними, культурними та технологічними змінами, наслідком яких став поділ на високе мистецтво і звичайне ремесло. Наведено особливості функиій, що здійснюють учасники процесу народження твору вітражного мистецтва. Окреслено взаємозв'язок професійних художників і робітників-виконавців вітражних виробів на прикладі Львівського вищого професійного художнього училищза, кафедри художнього скла Львівської національної академії мистецтва та підприємств скляної галузі. Виділені проблеми підготовки вітражників-виконавиів, запропоновано шляхи їх розв'язання.

Ключові слова: відродження; вітражне мистецтво; професійна (професійно-технічна) освіта; робітник; Львівщина.

Jim. 6.

Lidiya Slipchyshyn, Doctor of Sciences (Pedagogy), Senior Research, Associate Professor of the Theory and Methods of Technological Education,

Drawing and Computer Graphics Department Mykhaylo Drahomanov National Pedagogical University, Kyiv

\section{CONTRIBUTION OF VOCATIONAL EDUCATION AND TRAINING IN THE REVIVAL OF STAINED ART IN LVIV REGION}

The contribution of vocational education and training to the revival of stained glass art in Western Ukraine and in particular in Lviv region is considered. The popularity of stained glass products in Western Ukraine is due to the development of this art in European countries and the opportunities for local development of the glass industry. The interrelation of the development of stained glass art with socio-economic, cultural and technological changes, which resulted in the division into high art and ordinary craft, is substantiated. High art has always been associated with the work of professional artists. The peculiarities of the functions performed by the participants in the birth process of a stained glass art work are given. It is shown that in modern conditions in the development of stained glass art there is a close cooperation of master performers and professional artists. The result of such cooperation is the improvement of products intended for the general public. The relationship between professional artists and 


\section{ВНЕСОКПРОФЕСЙНОЇ(ПРОФЕСІЙНО-ТЕХНІЧНОӤ) ОСВІТИ}

У ВІДРОДЖЕННЯ ВІТРАЖНОГО МИСТЕЦТВАНАЛЬВІВЩИНІ

stained glass workers is outlined on the example of the Lviv Higher Vocational Art School, the Department of Art Glass of the Lviv National Academy of Arts and glass industry enterprises. In order to train the specialists-performers in the educational institution of vocational education, a standard of the stained glass profession was developed, the new edition of which expanded and deepened the possibilities of the profession. In order to revive the traditions of stained glass in Western Ukraine, a Center was established on the basis of the institution, which provides educational services for various segments of the population in mastering its art. The problems of the glass industry development in Ukraine are highlighted and the attitude of the Association of its producers to the artistic aspect of production is revealed. The problems of stained glass performers training are identified and ways to solve them are suggested.

Keywords: revival; stained glass art; vocational education and training; a worker; Lviv region.

П остановка проблеми. У рукотворних об'єктах творець демонструє глибину власного розуміння взаємозв'язку людини, простору і Космосу. Через емоційну відкритість образне наповнення твору здатне виявити його внутрішню енергетику, яка через складні асоціативно-метафоричні уявлення наповнює людину духовними цінностями. Залежно від художньо-естетичного досвіду в різних регіонах з'являється розмаїття етноестетичної матеріалізації та традицій народної мистецької ментальності. Ця ментальність лежить в основі високої художньої творчості, яка матеріалізується у різних видах мистецтва. Поміж різновидів мистецтва знайшов своє місце і вітраж, який у Західній Україні має вікові традиції.

Як явище, вітражне мистецтво тісно пов'язане 3 соціально-економічними, культурними та технологічними змінами, наслідком яких став поділ на високе мистецтво і звичайне ремесло. Проте про який би рівень не йшла мова, твір народжувався у співпраці художників, архітекторів і виконавців. Замовники диктували тематику, художники вибирали матеріали для використання і техніку виконання, робітники виконували роботу.

Оскільки основним матеріалом для вітражів $\epsilon$ скло, то занепад і відродження цього виду мистецтва пов'язані з соціально-економічними обставинами та специфікою регіонального розвитку скляної галузі. На зламі XX - XXI ст. відбувається чергове відродження вітражного мистецтва, викликане динамізмом суспільноекономічних змін і можливістю залучати до нього не лише професіоналів, але й тих, хто прагне розкрити творчий потенціал, освоїти новий вид творчості та художній бік професійної діяльності. Сучасні техніки й технології вітражу дали поштовх виробництву широкого асортименту художніх та ужиткових виробів, що актуалізувало проблему підготовки відповідних фахівців не лише в закладах вищої, але й професійної (професійнотехнічної) освіти (П(ПТ)О).

Аналіз останніх досліджень та публікацій. Розглядаючи становлення вітражу як виду мистецтва (Ю. Бірульов, І. Гах, Д. КапчинськаКлєщинська, П. Карашкевич, О. Нога, В. Рагін, К. Павловська, М. Хиггинс), його художньо- стильові, художньо-композиційні та регіональні особливості (Н. Гіляєва, Р. Грималюк, О. Пронін, М. Радомський, О. Самойленко), не можна оминути ще двох важливих аспектів, які впливають на його розвиток - це історія вітчизняного склоробства (М. Безбородов, В. Рожанківський) і художнього скла (А. Бокотей, М.Бокотей, Т.Кара-Васильева,А. Ланцетті,М. Нестеренко, О. Тищенко, 3. Чегусова) та професійна підготовка відповідних фахівців (Л. Масол,В. Радкевич, В.Сліпак). Як показав аналіз напрацювань і досліджень, нині залишається малодослідженою проблемою участь системи професійної (професійнотехнічної) освіти у відродженні в Україні вітражного мистецтва.

Метою статті $\epsilon$ виявити внесок системи професійної (професійно-технічної) освіти у відродження мистецтва вітражу в Західній Україні, зокрема на Львівщині, і показати сучасні проблеми, які стоять перед освітнім закладом, що готує вітражників-виконавців.

Виклад основного матеріалу. Вітраж своєю композицією, наповнюваністю і кольоровою гамою психологічно впливає на людину, яка, залежно від зовнішніх умов, може по-різному його сприймати. Недаремно найбільш відомі вітражні твори розміщені у сакральних спорудах. Не лише через тематику твору вони здатні викликали духовне піднесення, але й через психологізм впливу на почуттєву сферу людей. Скло дає змогу передавати не лише тематичні сюжети, але й музику скла, в якій $є$ багато символізму. Потяг людини до інтенсивних естетичних вражень спонукає ії до потреби навчитись відокремлювати ефекти від природного контексту, який і $\epsilon$ джерелом такого переживання. Естетичне переживання від споглядання мистецького твору породжує в глядачів емоції, що мають здатність викликати відчуття плинності часу, простору, величі, а можуть і бентежити, і провокувати, і надихати до творчих пошуків. Це нагадує своєрідне розхитування “естетичного" маятника (за Й. Шиллером).

Зрозуміти роль випускників системи П(ПТ)О у відродженні вітражного мистецтва можуть допомогти концептуальні засади естетичної гри якпроцесу, запропоновані філософом Г.-Г.Гадамером. 


\section{ВНЕСОКПРОФЕСІЙНОЇ(ПРОФЕСІЙНО-ТЕХНІЧНӦ̈)ОСВІТИ}

\section{У ВІДРОДЖЕННЯ ВІТРАЖНОГО МИСТЕЦТВА НАЛЬВІВЩИНІ}

Він уважав, що основними учасниками естетичної гри є художник, критик, ремісник і аудиторія, кожен 3 яких виконує важливу функцію. Художник інтерпретує глибинні потреби часу, відкриває для суспільства горизонти нових епох, формує свою аудиторію, яка підтримує його в процесі творчих пошуків і допомагає завойовувати ринок. Критик не дає художнику відривати мистецтво від повсякденного життя і допомагає здійснювати комунікацію 3 аудиторією. Аудиторія може активно сприйняти нове або повністю його відкинути. Потреби і попит приводять до тиражування результатів вдалої ідеї, а естетичній грі більш властиві бажання і пристрасті, що сприяє розвитку високого мистецтва. На шляху між високим мистецтвом і масовим тиражуванням особливу роль виконує ремісник. В естетичній грі він інтерпретує, збагачує мистецтво і виходить за межі звичайного відтворення [4, 99 - 101]. Для висококваліфікованого ремісника важливо вийти на рівень творчої свободи, оскільки це допомагає йому знайти власний стиль професійної діяльності і уникнути шаблонності, масовості.

Естетична компетентність фахівця у галузі роботи зі склом завжди втілюється у його професіоналізмі. Розглядаючи працю робітника зі склом, можна дистанціюватись від естетичного та оперувати техніко-економічними категоріями (витрати, методи виробництва, раціоналізація праці, технологічні зміни, масове і серійне виробництво). Водночас сучасні технологічні зміни розширюють можливості виробництва, в тому числі й скляних виробів. Вони гостро ставлять проблему переосмислення ролі технологій галузі та осягнення їхнього естетичного коріння і потужності потенційної естетичної енергії.

Мистецтво створення вітражу потребує відповідного навчання, яке формує професійне володіння технологічним процесом водночас із підвищенням рівня художньо-естетичного виконання. Щоб створити унікальний вітраж, необхідно знайти свій неповторний стиль, в якому мають поєднатися складні композиційні рішення стосовно форм і кольорів, узагальненість форм, лаконізм і декоративність. Важливе значення має застосування різних мотивів, характерних для етнокультурних середовищ.

Сучасні критики мистецтва та менеджери артсфери, спираючись на погляди Г. Гегеля, Ф.В.Й. Шеллінга, У. Джемса, Дж. Дьюї, схильні до думки, що “мистецтво сприяє демократії, вводить у сферу високої культури і культуру популярну, масову” $[4,78]$. Будь-яка регіональна культура, відмовившись від етноцентризму, але зберігаючи і примножуючи етнотрадиції, здатна збагатити людську культуру, сприяти комунікаціям між людьми і відкрити шлях до сприйняття універсальності природи.

На мистецькій мапі художнього скла України, як зазначає З.Чегусова, вирізняється досвід львівських митців, в якому простежуються наступність традицій, багатоманітність образнопластичних рішень і вишуканість декорування. Творчий експериментальний пошук спрямовувався на знаходження власного стилю, новітніх образних i формальних художніх задумів. Львівське художнє скло є “винятковим явищем, яке охоплює творчість плеяди видатних народних майстрів та професійних художників”. Спільним для художників-професіоналів і народних майстрів на зламі століть стало розуміння необхідності зміни принципів формотворення і відхід від утилітарності. Художньо-естетичний рівень і творчий поступ виробів львівського гутництва яскраво проявлявся в індивідуальній творчості [6].

Улітку 1999 р. була заснована перша та єдина в Україні професійна Асоціація художниківвітражників “Вікно”. Підсумовуючи здобутки львівських митців за двадцять років діяльності Асоціації, I. Гах зазначила, що учасники як у художньому, так і технологічному аспектах перебувають у неперервному творчому пошуку, піднімаючи мистецтво вітражу на вищий щабель. Актуальним висновком стала констатація того, що формально-образні відкриття Асоціації упродовж другого десятиліття XXI ст. “пропонують широкий шлях до пізнання “секретів” мистецтва вітражу, власними напрацюваннями спрямовують цю галузь на подальшу перспективу розвитку та вдосконаленняо [3]. Біля витоків Асоціації стояли митці, які працювали у різних закладах як вищої професійної, так і професійно-технічної освіти, а також на виробництвах скляної галузі. Зокрема, іiі членами були педагоги тогочасного львівського ПТУ-12 - А. Винту, О. Личко і Ю. Павельчук.

У пошуках сучасних форм художнього скла тісний зв'язок професійного і народного мистецтва матеріалізувався у проєктній діяльності професійних художників і народних майстрів. У цьому контексті М. Бокотей наводить приклади Львівської експериментальної керамікоскульптурної фабрики (ЛЕКСФ), Львівського ВО “Райдуга" та Київського заводу художнього скла, на яких, окрім професійних художників, працювали й талановиті ремісники. Зокрема, на ЛЕКСФ працювали Б. Валько, Й. Гулянський, П. Думич, Р. Жук, М. Павловський та багато інших [2]. Цей перелік можна продовжити і в межах України, 
адже в $60-80$-х рр. в СРСР досить поширеною була практика на промислових підприємствах багатьох галузей мати різні за розмірами i, відповідно, потужністю експериментальні цехи, де розв'язувались питання художнього характеру і водночас виготовлялись художні вироби (сувенірна продукція, іграшки тощо).

На львівському заводі “Райдуга" працювала потужна група художників (О. Богуславський, Л. Віхарєва, В. Гінзбург, О. Ласовський, Л. Нагорний, Р. Шах), якій вдалось наблизити рівень художньої продукції до світових стандартів, про що свідчили популярність львівського художнього скла i виставки різних рівнів. Одна 3 виставок 3 символічною назвою “Скло, художник, завод” відбулась у 1984 р. у Львівському музеї етнографії та художнього промислу. Щоб втримати творчі досягнення на високому рівні, керівництво заводу було зацікавлене у поповненні виробничого колективу молоддю 3 належною професійною підготовкою до роботи з художнім склом.

3 приходом на педагогічну роботу в львівське будівельне ПТУ-12 випускника Львівського інституту прикладного і декоративного мистецтва (нині це ЛНАМ - Львівська національна академія мистецтв) Ю. Павельчука у закладу з'явилася можливість розширити освітні послуги і для потреб скляної галузі ввести нову професію виконавець художньо-оформлювальних робіт. У 1982 р. в училищі був створений новий відділ, орієнтований на художні професії, що стало передумовою нового етапу розвитку закладу. Перший випуск робітників художнього профілю для скляної галузі відбувся у 1985 р. У межах СРСР це було перше ПТУ, що випускало робітників для скляної галузі. На навчання приїжджали учні із союзних республік (Вірменія, Литва, Латвія, Росія), які після його закінчення здобуті знання, вміння і навички застосовували на підприємствах своїх країн. Учні спеціалізувались у напрямах видування скла (склодув), розпису по склу (живописець по склу), гравіювання і різьблення по склу (гравірувальник і різьбяр по склу), вітражу (вітражник), видування і оздоблювання гутним способом.

Завдяки взаємному розумінню керівництвом ВО “Райдуга" та ПТУ-12 проблем виробництва, професійної підготовки і творчих мистецьких пошуків на базі училища у 1990/1991 н.р. було створено навчально-виробничий комплекс, який очолив професійний художник-скляр О. Личко. До його складу входив цех гутних виробів, який розташовувався на території училища і де учні проходили виробничу практику. Багаторічним куратором з боку підприємства був Ю. Гріс.
Наприкінці навчального року (1992) у Львівському національному музеї українського мистецтва пройшла виставка авторських робіт учнів і працівників закладу, яка показала високий художньо-естетичний та виконавський рівень виробів.

На початку 90-х рр. ХХ ст. у Західній Україні почалось інтенсивне будівництво і реставрація сакральних споруд. До цього процесу долучились педагоги ПТУ-12-А. Винту, О. ЛичкоіЮ. Павельчук. Вони разом $з$ учнями працювали над вітражами церков Св. Анни, Святих Ольги та Слизавети, новозбудованої церкви Вознесіння Господнього та інших. Відповідно, у професії “виконавець художньо-оформлювальних робіт” набула актуальності спеціалізація у вітражному мистецтві, що було хорошим знаком для закладу. Станом на 1999 р. в училищі вже функціонували художній і будівельно-реставраційний відділи, що дало підставу у 2003 р. реорганізувати заклад у професійний художній ліцей, а в 2010 р. - у ДНЗ “Львівське вище професійне художнє училище" (ЛВПХУ).

Відповідно до світової практики професійної освіти і навчання, з 2002 р. в Україні розпочалась розробка і впровадження державних стандартів професій згідно з державним переліком фахів та чинним на той час державним класифікатором професій ДК 003-95. У 2004 р. було розроблено перший стандарт ПТО професії “Вітражник”, який грунтувався на освітньо-кваліфікаційній характеристиці випускника, складеній на основі Довідника кваліфікаційних характеристик професій працівників розділу “Рекламна та реставраційні роботи” (Випуск № 86, 1985 р.), у процесі створення якого взяли участь викладачі художніх спеціальних дисциплін О. Дуфанець і О. Погребняк. 3 уведенням в дію нового класифікатора професій від 2010 р. і зміною вимог ринку праці у 2014 р. було прийнято стандарт ПТО професії “Вітражник” у новій редакції, на основі якого можна готувати фахівців $2-6$ розрядів. Оскільки вітражник є спеціалізованим фахом, його освоєння відбувається у рамках інтегрованої професії “Живописець. Вітражник” у два етапи.

Останнім значним досягненням закладу є участь в 2019 р. у проєкті Українського культурного фонду “Створення Центру вітражного мистецтва на базі ДНЗ “Львівське вище професійне художнє училище” для збереження культурної спадщини українського вітражу”. Проєкт продемонстрував, з одного боку, велику зацікавленість громади і освітян у розвитку мистецтва вітражу з урахуванням його традицій та сучасних можливостей, a, з іншого боку, 
показав реальні можливості закладу готувати кваліфікованих вітражників-виконавців та надавати освітні послуги для різних верств населення в опануванні мистецтва вітражу.

Щоб зрозуміти перспективи розвитку вітражного мистецтва на Західній Україні та підготовки фахівців-виконавців, доречно порівняти сьогоднішні передумови в двох найпотужніших центрах вітражного мистецтва в Україні, тобто у Києві та Львові.

Станом на 1991 р. в Україні працювало 40 підприємств скляної промисловості, серед яких 4 заводи виробляли листове і технічне скло, 10 сортовий посуд, 6- дзеркальні вироби, 13 - пляшки i тарне скло. Львівське скляне ВО "Райдуга" і єдиний український завод художнього скла у Києві входили до групи найбільших підприємств [5, 198]. 3 переходом до ринкової економіки багато з них потрапили у скрутне фінансове положення і не всі змогли втриматись на ринку. Зате з'явилася можливість самозайнятості, яку легше було здійснити, маючи творчу професію.

У 1995 р. ВО “Райдуга" припинило існувати як державне підприємство і змінило форму управління на Акціонерне товариство закритого типу “Склодар”, яке збанкротувало у 2000 р. Здійснення основної діяльності продовжувалось, але на засадах приватного підприємництва. Водночас виникло багато дрібних фірм, які серед послуг вказують виробництво вітражів, а значить і потребують молодої генерації працівників. Єдиний в Україні заклад П(ПТ)О - ЛВПХУ плідно працює над удосконаленням професійної підготовки вітражників-виконавців, найкращі 3 яких поповнюють лави студентів ЛНАМ. Жодна виставка виробів, виготовлених учнями системи П(ПТ)О Львівщини, не обходиться без участі закладу та експонування виробів вітражного мистецтва.

У листопаді 1997 р. для консолідації зусиль виробників в умовах переходу до ринку була створена Асоціація підприємств скляної промисловості “Скло України”, яка сьогодні нараховує майже 60 членів - українських та іноземних підприємств, що працюють в цій галузі [1]. Серед них є і Київський завод художнього скла. Оскільки галузь інтенсивно розвивається, Асоціація впровадила систему централізованої підготовки кадрів, яка в кластері об'єднує профільні кафедри закладів вищої освіти і створений коледж 3 підготовки кадрів для скляної галузі. Заплановано також у межах кластеру відкриття майстерні для збереження школимайстрів Київського заводу художнього скла. Об'єднання долучається до випуску спеціалізованої літератури, надає можливість проходження виробничої практики, впровадило іменну стипендію для відзнаки найкращих студентів, заснувало WEB-сторінку АПСП “Скло України”, разом із видавництвом “Світ Успіху” видало книгу із серії “Майстри своєї справи “Скло України” та дайджест “Скло\&Світ” [1]. Воно не лише популяризує галузь, прагне поліпшити умови роботи підприємств, але й налаштоване на збереження найкращих традицій українського художнього скла.

Результат порівняння передумов розвитку вітражного мистецтва в Києві та Львові як мистецьких центрів та участі в цьому процесі системи П(ПТ)О дав підставу для таких висновків.

Висновки. Сьогодні найбільш тривожним сигналом для розвитку вітражного мистецтва на Західній Україні i, зокрема на Львівщині, є відсутність підприємств, що випускають якісне скло для відповідних виробів. Ті підприємства, що залишились, в більшості випадків переїхали у райони, що здешевило виробництво скляних виробів. Відсутність у них далекосяжної стратегії розвитку вплинуло і на регіональне замовлення кадрів - фахівців скляної галузі. Проте якість професійної підготовки в ЛВПХУ вітражниківвиконавців, художньо-естетичний рівень їхніх робіт дає змогу випускникам продовжувати навчання i здобувати вищу професійну художню освіту. Фах вітражника за наявності непересічних творчих здібностей та індивідуального творчого почерку має значний потенціал самозайнятості. На користь цієї тези свідчать факти зростаючого попиту на вироби для інтер'єрів, виготовлених у технології вітражу, а також класичний вітраж, що застосовується в сакральному і житловому будівництві.

Львівщина має вигідне становище стосовно збереження традицій вітражного мистецтва і його культурної спадщини, позаяк тут сформувалася потужна школа художнього скла в ЛНАМ та функціонує єдиний в Україні заклад П(ПТ)О для підготовки вітражників-виконавців. Нині цей освітньо-мистецький зв'язок потребує активної підтримки Асоціації підприємств скляної промисловості “Скло України”, що дасть можливість у майбутньому в двох мистецьких центрах України - Києві та Львові - створити повноцінний комплекс, налаштований на збереження найкращих традицій українського художнього скла.

Надалі дослідження буде продовжуватись у контексті організаційно-методичного аспекту професійної підготовки майбутніх робітників- 
вітражників в закладах П(ПТ)О в умовах дуальної освіти.

\section{ЛІТЕРАТУРА}

1. Асоціація Підприємств Скляної Промисловості “Скло України”. URL: http://sklo.kiev.ua/?mid=2 (дата звернення 23.04.2020).

2. Бокотей М. Художнє скло в українській системі термінологічного-понятійного апарату класифікації мистецтва. Вісник Львівськой національної академї мистецттв. Львів, 2017. Вип. 32. С.72-85.

3. Гах I. Кольорове світло серця і душі. URL: https://zbruc.eu/node/91207 (дата звернення 02.08.2019).

4. Гуле де Монто П. Арт-фирма: Эстетический менеджмент и метафизический маркетинг / пер. с англ. Київ : Companion Group. 2013. 416 c.

5. Скляна промисловість. Географічна еничиклопедія України. Т.3: П-Я. Київ : “Українська енциклопедія" ім. М.П. Бажана, 1993. $480 \mathrm{c}$.

6. Чегусова 3. Панорама Львівського гутництва на межі XX - XXI століть: експериментальні пошуки творчих індивідуальностей. URL: https:// www.glassymposium.org/ukrainian-glass.html (дата звернення 28.04.2020).

\section{REFERENCES}

1. Asotsiatsiia Pidpryiemstv Sklianoi Promyslovosti "Sklo Ukrainy" [Association of Glass Industry Enterprises
"Glass of Ukraine"]. Available at: http://sklo.kiev.ua/ ?mid=2 (Accessed 24April 2020). [in Ukrainian].

2. Bokotei, M. (2017). Khudozhnie sklo v ukrainskii systemi terminolohichnoho-poniatiinoho aparatu klasyfikatsii mystetstva [Art glass in the Ukrainian system of terminological and conceptual apparatus of art classification]. Bulletin of the Lviv National Academy of Arts. Lviv, Issue 32. pp. 72 85. [in Ukrainian].

3. Hakh, I. (2019). Kolorove svitlo sertsia i dushi [Colored light of heart and soul]. Available at: https:/ /zbruc.eu/node/91207 (Accessed 20 April 2020). [in Ukrainian].

4. Gule de Monto, P. (2013). Art-firma: Esteticheskiy menedzhment $i$ metafizicheskiy marketing [Art Firm: Aesthetic Management and Metaphysical Marketing]. Kyiv, Companion Group. 416 p. [in Russian].

5. Skliana promyslovist (1993). [Glass industry]. Geographical encyclopedia of Ukraine. Vol. 3. Kyiv, "Encyclopedia of Ukraine" after named M.P. Bazhana. 480 p. [in Ukrainian].

6. Chehusova, Z. Panorama Lvivskoho hutnytstva na mezhi XX-XXI stolit: eksperymentalni poshuky tvorchykh indyvidualnostei [Panorama of Lviv Gutnytsia at the turn of the XX - XXI centuries: experimental search for creative individuals]. Available at: https://www.glassymposium.org/ ukrainian-glass.html (Accessed 28 April 2020). [in Ukrainian].

Стаття надійшла до редакції 22.05.2020

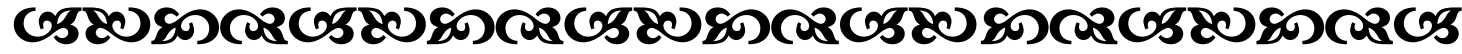

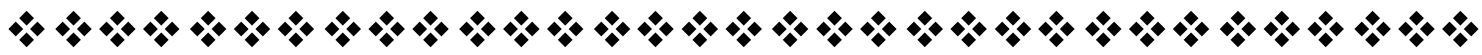

"Тедагогіқа - не науқа, а мистеитво, - найобширніше, сқладне, найвище й найнеобхідніше з усіх мистеитв. Мистеитво виховання спирається на науқу. Яћર мистецтво складне й обширне, воно спирається на безліч обширних і складних наук; як мистецтво, воно, қрім знань, вимагає здібності й нахилу, $і$ якмистештво Ж, воно прагне до ідеала, яқого вічно намагаються досягти і яқий иілком ніколи недосяжний: до ідеала довершеної людини. Сприяти розвиткові мистеитва виховання можна тільки взагалі поширенням серед вихователів тихнайрізноманітніших антропологічних знань, на яқих воно грунтується".

Костянтин УУшинський уқраїнський педагог

"ТТалант без роботи так само поганий, якробота без таланту".

Анатоль де Франс франиззъцй прозайк, літературний қритик

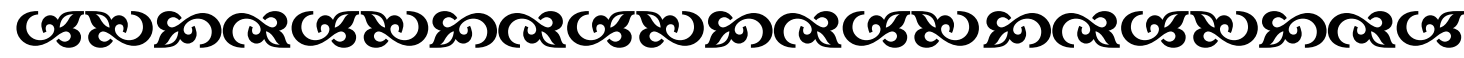

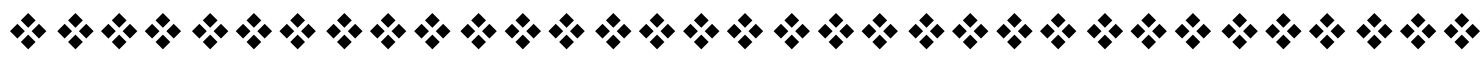

